\title{
Comparative Study of Chanoyu Tea and Tea Serving in Yogyakarta Palace
}

\author{
Teti Indriati Kastuti ${ }^{\mathrm{a}}$, Christine Dian Permatasari ${ }^{\mathrm{b}}$ \\ University of Technology Yogyakarta, Jl. Siliwangi Jl. Ring Road Utara Jombor, Yogyakarta 55285, Indonesia \\ Email: tetiindriati@uty.ac.id
}

\begin{abstract}
The researcher's experience of studying chanoyu for one year at Urasenke Kyoto became a stimulus to compare Chanoyu tea serving ceremony and tea serving ceremony in Yogyakarta Palace. Up to this time, the tea serving ceremony in Yogyakarta Palace has never been opened to the public, unlike the worldwide Chanoyu tea serving ceremony, a particular school has even been opened to study chanoyu. With this phenomenon, researchers are interested in examining further to compare the two tea serving ceremonies. The method used is descriptive qualitative with literature study, field observation, and interview. The results show that tea used in chanoyu was called powdered matcha, while in Yogyakarta Palace it was 2 Tang powder tea. The utensil in chanoyu is free to choose according to the guests and the season. At the same time, in Yogyakarta palace, it has become the rule and only for families in Yogyakarta Palace. The philosophical meaning of chanoyu is related to the harmony seen in the interaction between participants, as well as between utensil and seasons, while tea serving in Yogyakarta Palace begins with the service of Abdi Dalem to his king. Both of them have similarities in the presentation that must follow the patent rules.
\end{abstract}

Keywords: Chanoyu; Palace; Tea

\section{Introduction}

Tea was always a potential world conqueror. Over the last two thousand years, its empire has spread, and it has become the greatest addiction in history. As the mythical or possibly legendary Chinese, Emperor Shen Nung is said to have put it: Tea is better than wine for it leadeth not to intoxication, neither does it cause a man to say foolish things and repent thereof in his sober moment (Macfarlane, 2004). Tea means many things to many people. It has a vibrant and intriguing history and can be considered to be a plant, an agricultural product, a beverage, a meal service or a pastime. Tea has been both the focus of colonization and the subject of revolutions. Tea is closely connected with the ancient and modern history of world trade and travel. Tea as a commodity and a tradition can be transported from one culture to another and through adaptation transformed from the traditions of one culture to the heritage of another (Prof. Lee Jolliffe, 2007).

Tea is one of the most favourite drinks for Indonesian people. Even so, many Indonesian people do not understand tea for the whole. Brewing tea seems like a straightforward thing, brew it with hot water. Behind this simple thing, some things must be considered. Tea is so special. Even though it comes from China, it can melt and becomes a country's culture when it is brought to another country. Thus, it creates many tea cultures in each country. Tea can belong to those countries, adapt to the people customs, and create various tea- 
drinking cultures. There are a lot of different ways to drink tea in various countries, even in Indonesia, there is the tea that typically belongs to several regions. Tea drinking habits differ from one region to the next, and Indonesia does not have elaborate tea ceremonies such as in China or Japan. Different regions have different tearelated habits and customs (Santhi, 2016). However, what can be said to be a tea ceremony with a relatively long ceremony, and the procedure is Chanoyu from Japan.

Chanoyu is often called Chado (the way of tea) which means hot water for tea. As a combination of the art of brewing tea with Zen teaching, the tea ceremony is the most complex in the world (Fajria Noviana, 2015). Zen (禅) comes from Japanese, while Sanskrit is dhyana. In China, it is known as Chan, which means meditation. The Zen school focuses on meditation to attain enlightenment or perfection. From the 12th and 13th centuries, further development of Zen school was Zen art, following the introduction of this school by Dogen and Eisai after they returned from China. Most of the time, Zen art has the characteristics of the original painting (sumi-e and enso) and poetry (haiku).

Rikyu often stressed the heart as the measure of all things beautiful, as had many medieval artists, poets, Noh actors, and painters before him. Wabi without heart becomes a meaningless pursuit, for the heart links the imperfection to perfection, the asymmetry to symmetry, eh whithered branch to is a fruit, the heart makes the socially unequal, equal, the ugly, beautiful (Plutschow, 1986). Despite having Chinese roots, chanoyu has been widely seen both within and outside of Asia as something inherently Japanese. It is often considered the hallmark of Japanese hospitality. One of the teachings contained in chanoyu is ichigo ichie which means, there is only one chance in a lifetime. Therefore, this event should be truly appreciated. This sentence can be said to be a form of super service (Suryawati, 2018). Sen Rikyu, the first and most famous of all tea masters, perfected the serene tea aesthetic called "wabi" based on serenity, harmony, simplicity, and respect for all things. In the other side, Indonesia is known to the world as one of the tea leaves producing country for industry. However, this does not mean that Indonesia does not have a classy drinking culture in the style of Eastern European and East Asian countries. Bumi Nusantara also has a culture of drinking Patehan tea, a daily tea ceremony at Yogyakarta Palace by Sri Sultan Hamengkubuwono. Currently, Patehan is still taking place in the scope of Yogyakarta Palace and at the Royal Ambarukmo Yogyakarta hotel, but at least it can be one proof that Indonesian tea also has its peculiarities. It is no longer solely for industrial purposes. This phenomenon encourages researchers to dig deeper into Patehan tea based on the researchers' experience of 1 year studying Chanoyu in Urasenke, Kyoto.

There were several studies conducted about chanoyu. Kastuti (2018) carried out a study to examine philosophical values in Chanoyu while Magdalena (2019) conducted a study on the implementation of Zen Buddhist principles in Urasenke Chanoyu ceremony (Magdalena \& Nuswantoro, 2019). Besides, Halim et al. 1 designed a book about Tradition of Patehan in Yogyakarta Palace. They examined the phenomenon in Yogyakarta palace on tea drinking routine (Halim et al., n.d.)

Different from the previous research, this study focuses on the comparison between tea serving in Chanoyu and Yogyakarta Palace. The researchers intend to describe: (a) comparison of the tea ingredients and utensils used in the serving ceremony of Chanoyu tea and tea in Yogyakarta Palace, (b) comparison of the philosophy contained in Chanoyu tea and tea in Yogyakarta 
Palace, (c) comparison of the procedures for their presentation. This presentation ceremony needs to be explored to compare the cultural values between Japan and Indonesia, especially the presentation of tea in Yogyakarta Palace in which until now no one has investigated the presentation of tea in Yogyakarta Palace. Hence, it gets a cross-cultural understanding between Indonesia and Japan. Theoretically, this present study can contribute cultural development on tea serving both in Chanoyu and Yogyakarta Palace. It could be used as a reference for conducting further research. Furthermore, the result of this study can provide learning information for the readers and writers about the procedure of tea servings in Chanoyu and Yogyakarta Palace.

\section{Method}

This research belongs to a descriptive qualitative study since to understand the phenomenon as a whole; of course, one must understand the whole context and carry out a holistic analysis with a descriptive explanation. Data collection techniques used in this research were literature study, observation, interview, documentation. Then triangulation data was used as an analysis technique. The following is a data collection technique:

1. The first stage

Desk research activities were carried out to obtain secondary data. Sugiyono stated that the results of the research would be more credible if they are supported by existing photographs or academic and artistic papers (Sugiyono, 2014). Literature study examining chanoyu in the form of journals and books was used in this research.

2. The second stage

Observation is conducted to find a real situation in the Yogyakarta Palace environment.

3. The third stage
The researchers also conducted a structured interview. The researchers used a list of questions that had been compiled previously. The structured interview was used to gain data on the right track. Interviews were conducted with Abdi Dalem Keraton Yogyakarta. Data from informants were used as primary data. The main informants were Abdi Dalem Reso and Keparak who were in charge of preparing drinks in Patehan Yogyakarta kitchen, Kawedanaan Hageng Purayakara Kangjeng Danu Kusumo, Penghageng Tepas Tandha Yekti, and representatives of Penghageng II KHP Widyabudaya (KRT Rintaiswara).

4. The fourth stage:

Documentation was also used in this study. Photo and video during the interview were used as documentation for this study.

Data collection procedure in qualitative research were divided into four basic types -qualitative observation, qualitative interview, qualitative document and qualitative audio and visual material. Photo and video documents are used to strengthen research. Verbal and non-verbal interaction between informants and researchers shape the data collected, which in turn affects the results of the study. The verbal or written questions must be appropriately formulated and adapted to the claims of the referenced method so that the researcher can find some understanding of the phenomena being studied (Bengtsson, 2016).

\section{Result and Discussion}

Ceremonies, customs, and ritual that have grown up around the practice of tea drinking are an integral part of the life and culture of many societies. In the Way of Tea, it is desirable to be natural and relaxed, mentally, and physically; that is, it is desirable to have a natural appearance. Begin with trying to sit seiza naturally. It should not appear to be forced to sit rigidly, 
nor should appear slack. It could be described as 'sitting at ease.' Chanoyu training begins with warigeiko, or "divided practice" of the essential elements (Soshitsu Sen XVI, 2010).

\subsection{Matcha as a tea used in chanoyu}

Matcha was initially brought from China by monks around the twelfth century and was drunk to help keep them awake during meditation. In addition to the actual drink, the matcha flavour is trendy in Japan, and its reputation has spread internationally as a health product (Britain, 2010). The fresh green colour and unique taste come from tea leaves that have not been fermented, oxidized, flavoured, or smoked. It is the purest form of tea can drink-just $100 \%$ pure tea leaves.

In chanoyu, matcha comes in two varieties: koicha (thick tea), and usucha (thin tea). Each guest will receive their bowl when served usucha, but the bowl is shared between guests in the case of koicha. The sharing of the thick tea is at the heart of the formal tea gathering. Koicha is served at a formal tea gathering. More like a paste or a creamy potage. It is the essence of chanoyu. Usucha is the most common way to drink matcha. It is the leading tea served at most of the informal gathering. In April, the matcha tea fields are covered to starve the leaves struggle for the sunlight, the chlorophyll level increases, and amino acids like theanine are produced. In May, the leaves are picked and then taken to the plantation where they are steamed, dried, and stone-ground into a fine powder.

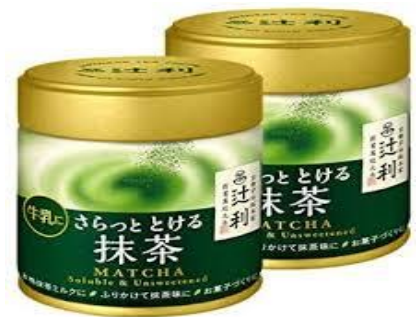

Figure 1 Matcha (tea used in Chanoyu)
Tang, tea used in tea serving at Yogyakarta Palace. Tea Factory "2 Tang " or CV. Duta Java Tea Industry which was formerly named Teh Tunggul Naga, was established in 1952 in the form of an individual. The owner is Sis Pramono who acts as President Director and as its Director is $\mathrm{Mr}$ Handoko. At the time of its establishment, the factory location was located at Jalan Raya Barat 5 Adiwerna Tegal Central Java Indonesia. Then the location was moved to the South Highway of Tembok Banjaran, Adiwerna Tegal. The name changed from PT. Dragon Stump to CV. Duta Java Tea Industry in 2010. Types of products produced by CV. Duta Java Tea Industry is aromatic tea. It was initially being produced two kinds, namely Tang brand and Djumput brand. The machine had not used the production process at that time. It used a kitchen called cubung. Cubung was used as a dryer using charcoal fuel. The materials used by 2 Tang factory in the production process were green tea, jasmine flower and gambier flower.

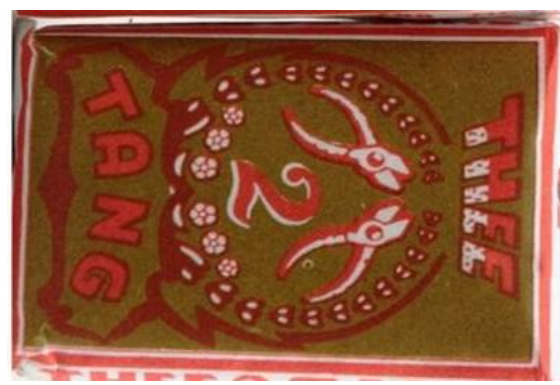

Figure 2 Tang tea

\section{Utensils (chadogu)}

Tea gatherings are based on specific themes. The host must give special consideration in bringing together utensils that will reflect the idea of that theme. Part of the enjoyment for the guests is to ponder what theme the host has chosen. For example, if the gathering is held in the summer, the host may want to suggest coolness. Selecting a shallow tea bowl and tea scoop with a name such as "dew" might help the guests feel cool. Formal gatherings 
tend to be more subdued, so the theme might be more complex to allow the guests to take their time contemplating the meaning over the day. Informal gatherings are more direct and demonstrate a poetic playful heart. The host brings together various utensils that differ in shape, size, colour, and material to try and create perfect harmony. Most of them are traditionally crafted tea utensils. Utensils used for a summer gathering (Soei, 2016)

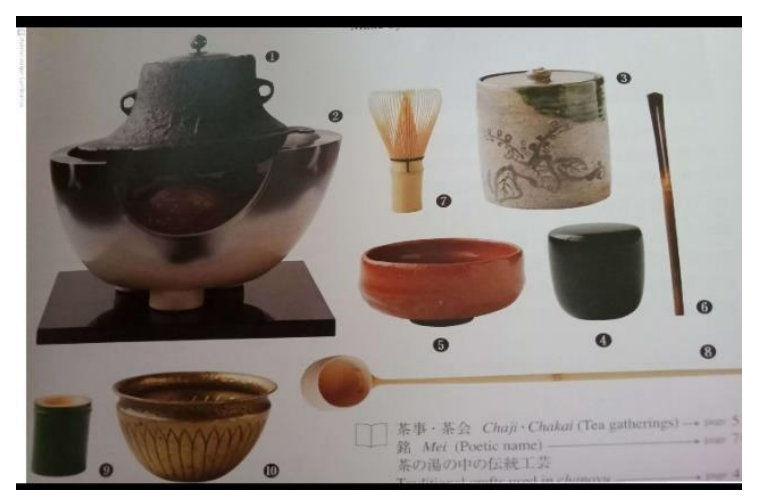

Figure 3 Chadogu (Tea Utensils in Chanoyu)

Table 1 The description of utensils used in Chanoyu (Figure 3)

\begin{tabular}{cll}
\hline No & Japanese & \multicolumn{1}{c}{ English } \\
\hline 1 & Kama & Kettle \\
2 & Furo & Brazier \\
3 & Mizusashi & Water container \\
4 & Natsume & Tea container \\
5 & Chawan & Tea bowl \\
6 & Chashaku & Tea scoop \\
7 & Chasen & Whisk \\
8 & Hishaku & Ladle \\
9 & Futaoki & Lid rest \\
10 & Kensui & Rinse water receptacle \\
\hline
\end{tabular}

\subsection{Rampadan/Utensil for tea serving at Yogyakarta Palace.}

On certain days, for example, the ceremony of Siraman Pusaka, Garebeg, Ngabekten ceremony, and tea utensils are taken out (Kuncoro, 2018). Some utensils such as trays, teapots, cups, saucers, spoons began to be removed from the storage area. It is also included a set of Rampadan (drinking utensil), especially for the Sultan. Before it is used, this utensil is cleaned first. When cleaning utensils for the Sultan, it must use warm water. All utensils are dried first and then wiped. After the ceremony is over, the utensils must be returned to Purayakara building.

Tea drinking utensils for Ngabekten ceremony at Yogyakarta palace are prepared according to the rules or regulations so that the Sultan, his relatives, Abdi Dalem, and guests used different drinking utensils. A unique set of Rampadan for the Sultan and Queen consists of a gold tray, a teapot set with floral motifs, a set of pink ceramic cups with the face of Sri Sultan Hamengku Buwono VII, and a gold spoon (picture a).

Before and after marriage, the drinking utensils of the Sultan' sons are different. When he was not married and still had the title Gusti, his drinking utensils consist of a silver tray, a flower-patterned ceramic teapot with a silver handle, a pink cup set, and a silver spoon. When he is married and has the title Kanjeng Gusti, his drinking utensils become a gold tray, a floral teapot with gold handles, a set of pink cups without pictures, and a gold spoon (picture b).

Sultan's brother also has different utensil. There is a set of yellow cups and silver spoons without Rampadan (picture c). Utensil for Sultan's son-in-law is a set of white cups and silver spoons without Rampadan (picture d). While for Wayah Dalem/grandson of the Sultan is set of blue cup and silver spoon, without Rampadan (picture e) and Abdi Dalem with the position as Regent, Wedana, Pengulon, and Juru Kunci use a set of white cups. (picture $\mathrm{f})$. Those various Rampadan is shown in figure 4 .

\subsection{Chanoyu and Japanese Spirit}

The Four Principles of Chanoyu are wa (harmony), kei (respect), sei (purity), and jaku (harmony). Harmony is shown in the interaction between the participants, as well 


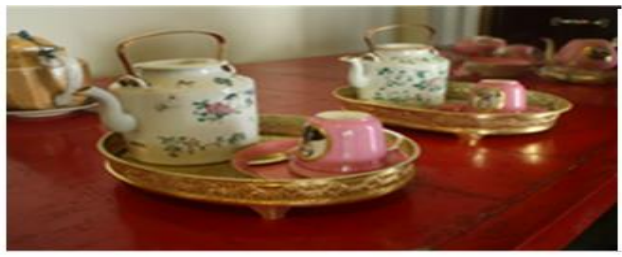

a

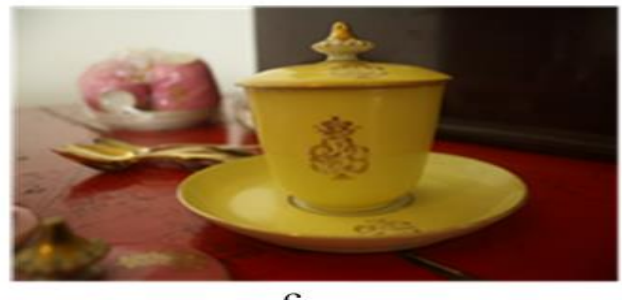

c

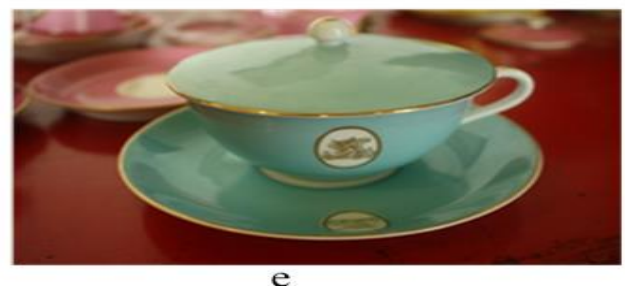

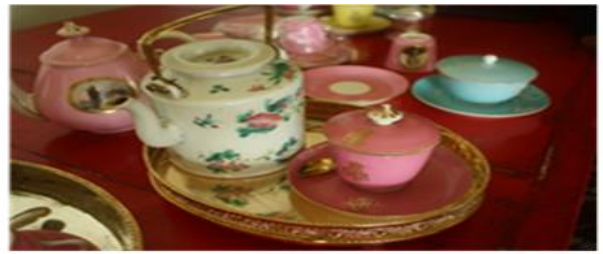

h

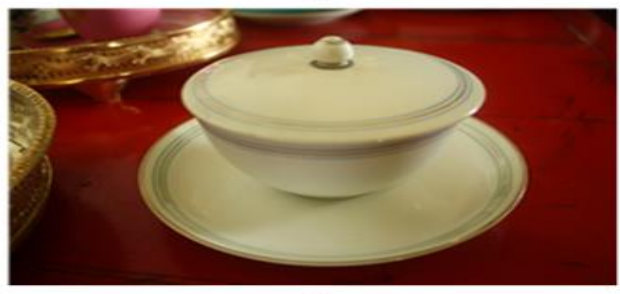

d

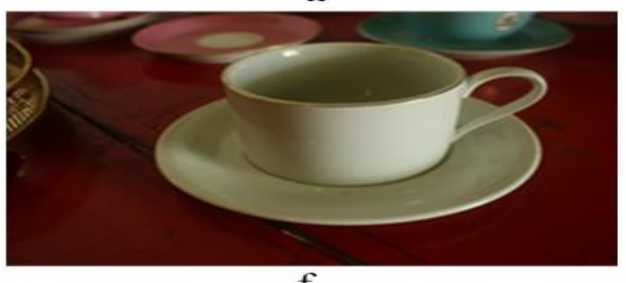

f

Figure 4 (a-f) Rampadan of Yogyakarta Palace

as between the utensils and seasons. Respect between host and guest, and between the guests themselves, is vital. Purity from the heart is extended to all present and the utensils. It is both spiritual and physical. Tranquillity, as mentioned before, can be attained when grasping the essence of the other three (Kastuti, 2018).

\subsection{Service of Abdi Dalem as one of the spirits of activity at Yogyakarta palace.}

The tea serving ceremony originated from the tradition of drinking the daily tea of the kings of Yogyakarta Palace in the past. However, the tradition of drinking tea began to change since the leadership of Sultan Hamengkubuwono (HB) IX. It is because, in King of Yogyakarta Palace, Sultan HB IX held several positions in the central government so that he stayed more often in Jakarta. Since that time, the tradition of drinking tea in Yogyakarta Palace has changed.

The tea making by Abdi Dalem Patehan was still done twice a day, but the finished tea was no longer served to the king. By Abdi Dalem Keparak, the tea and other drinks were brought to Gedhong Prabayeksa, where they were left to rest until it was time to replace them with new ones. Until now, the tradition of serving tea to Gedhong Prabayeksa is still being maintained. Reso is the name of Abdi Dalem who works in Patehan kitchen and is assisted by an assistant called Bekel. Reso Agus said that he had served for more than 30 years in Patehan kitchen where Patehan kitchen was a kitchen that specialized in making tea drink. The tea used is Tang tea. Based on Reso's information, they became servants of Yogyakarta palace solely to serve. Javanese people in their life believe in 2 worlds, namely Jagad Gede (large universe) and Jagad Cilik (small universe). The highest small universe is the King / Sultan, while the lowest is kawulo (people). Between the people and the Sultan are not bound by paying but tied to feelings and devotion. Sultan protects the king, then the people who feel nurtured then serve. The nature of his total devotion, meaning that he never counted how long he was devoted to 
the Sultan and what was asked to him. Abdi Dalem felt paid off in his life if one of their children could replace him.

\subsection{Procedure (Temae) in Chanoyu}

In chanoyu, the host makes a bowl of the tea using a series of prescribed motions called temae in front of the guests. In Japanese performing arts, kata (predetermined forms) are essential. The temae could be considered a form like in the martial arts. The host begins by settling his heart and mind by focusing on breathing. The host then goes through a series of movements that flow naturally and smoothly from the opening purification to the serving, and finally the closing. The procedure ( $\mathrm{ki}$ yomeru, tateru, serving) for making tea is a form of hospitality.

In kiyomeru, the host purifies the utensils in front of the guests. The symbolism of purity is indispensable in chanoyu. In tateru (making), for a bowl usucha, the host adds the right amount of tea (about $1.5-2 \mathrm{~g}$ ) and about $50-60 \mathrm{ml}$ of water heated to around $90^{\circ} \mathrm{C}$ to make the best tea for the guests. In serving, the host turns the tea bowl twice so that the front of bowl faces toward the guest.

The host makes the tea with the front of the bowl- sometimes represented by a notable feature or pattern- facing him. When the tea is made, the bowl is turned, so the front is facing the guests. The guests, out of humbleness and respect, turn the front away to avoid drinking directly from that spot (Genshitsu Sen, 2004).

\subsection{Preparation of serving tea in Patehan's kitchen}

The name Patehan is taken from the place where the tea-drinking tradition is carried out, namely in the Patehan ward. Patehan is a particular room for preparing and brewing tea drinks which are served to kings, families and guests (Somantri Ratna, 2014).
This process begins with preparing a fireplace and drawing water from Nyai Jalatunda well. There are a pair of wells in Patehan's kitchen which are used to meet the needs of making drinks. Well of Nyai Jalatunda (figure 6) on the west side is explicitly used for making drinks, while well of Kiai Jalatunda (figure 5) on the east side is used for washing activities.

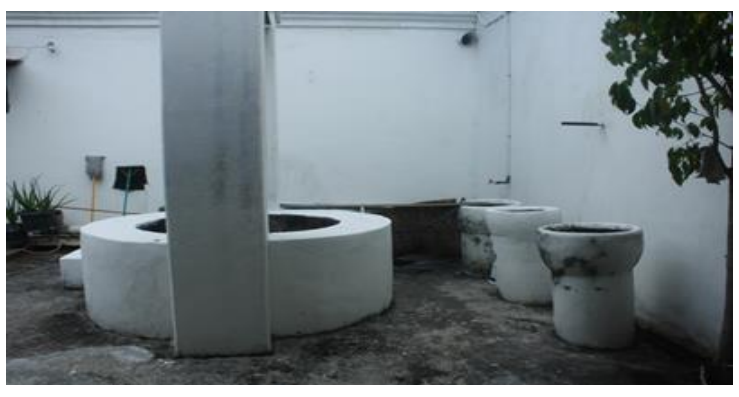

Figure 5. Well of Kiai Jalatunda

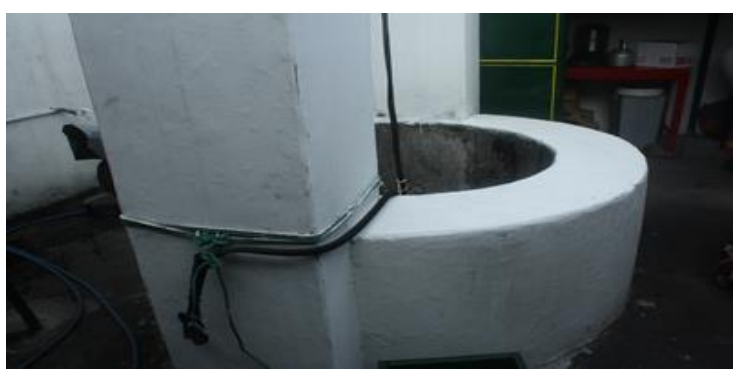

Figure 6 Well of Nyai Jalatunda

Water from Nyai Jalatunda is cooked in a special kettle made of copper. The kettles are called Kiai Wiji (figure 7). Copper was chosen because it is believed to be able to neutralize water as well as repel reinforcements.

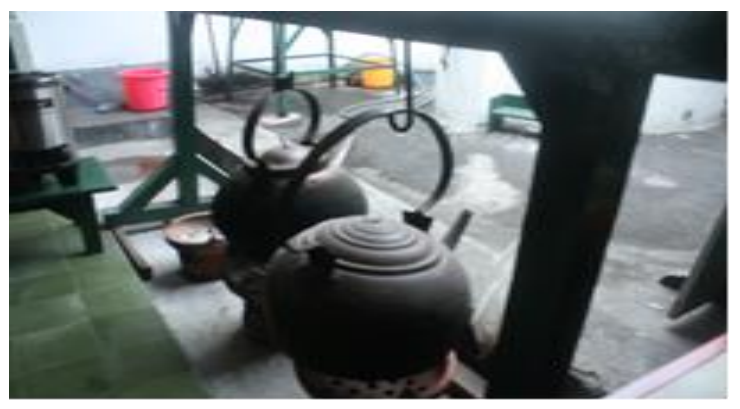

Figure 7 Kettle of Kiai Wiji 
Once cooked, the water is used as a tea brewer to make Dedokan. Dedokan tea is a very thick brew of tea which is later diluted with plain water when served. Dedokan allowed standing for half an hour without stirring. When ready, half of the Dedokan is transferred to a unique teapot for the king / Sultan. The remaining half will be given to Abdi Dalem Keparak who served as a taster. If still have left Keparak, Abdi Dalem Patehan will drink the excess. The purpose of tasting is to ensure that tea drinks are safe to serve to the King / Sultan. It is proof of the dedication of Abdi Dalem to the Sultan. During the process of mixing drinks for the Sultan, Abdi Dalem was required to wear a Samir.

Samir indicated that Abdi Dalem was on duty. Samir is a complete outfit for Abdi Dalem at Yogyakarta Palace. They were shaped like a ribbon or small sash with Gombyok decorations on both sides. At first glance, Samir only functions as an accessory, but Samir is an essential complement, and not just anyone may wear it. In the Yogyakarta Palace, Samir is a sign that Abdi Dalem who wears it is carrying out his duties called ayahan. These duties can be in the form of duty within the palace environment such as carrying heirlooms, bringing food to the Sultan, giving offerings, playing gamelan, or when teaching in the official palace forums, and also when carrying out tasks outside the palace environment, such as being a messenger in Labuhan or Garebeg ceremonies.

Apart from being a sign of duty, Samir also showed differences in the ranks of Abdi Dalem. Samir was differentiated based on the rank of Abdi Dalem who wore it. The primary material of Samir is Cindhe cloth with white and black motifs on a red basis, or often called Cindhe Bang-Bangan. Cindhe cloth, also called Cindai or Patola, is the name of a silk cloth made using a double tied technique.

Besides making tea, Abdi Dalem Patehan also prepares all the utensils and additional drinks. All this is brought by Abdi Dalem Keparak who assigned to bring the tea that is ready to serve to Gedhong Prabayeksa. Likewise, Abdi Dalem Keparak is assigned to bring tea that must be replaced with the new ones from Gedhong Prabayeksa to Gedhong Patehan. The number of Abdi Dalem is five people based on their needs.

The procession of serving tea in Patehan's kitchen by Abdi Dalem Reso is presented in the figure 8 .

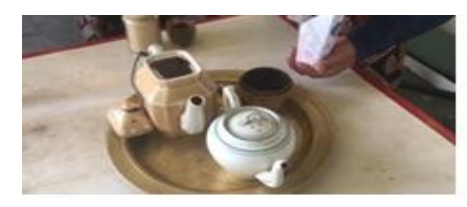

a

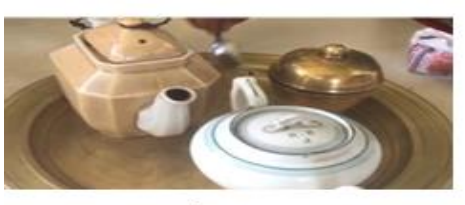

d

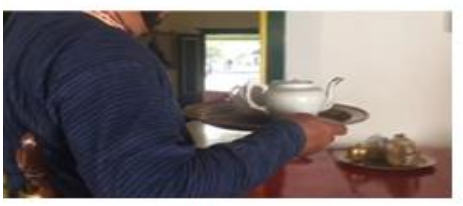

g
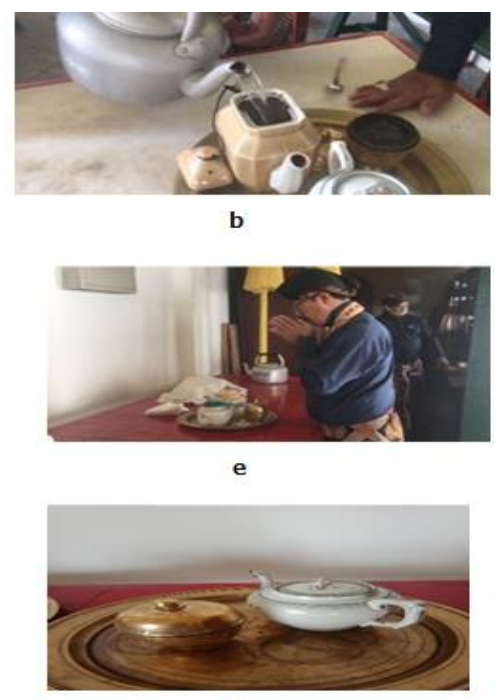

h

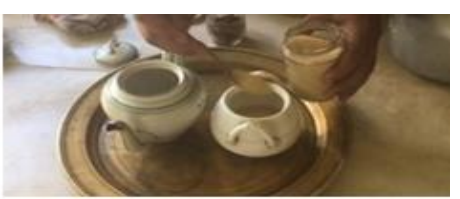

c
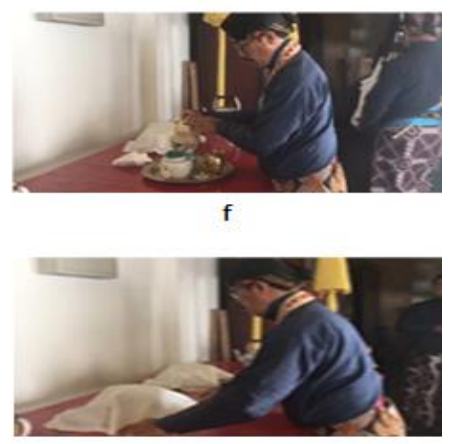

Figure 8 (a-i) Serving Procession 
IZUMI, Volume 9 No 2, 2020, [Page | 174]

e-ISSN: 2502-3535, p-ISSN: 2338-249X

Available online at: http://ejournal.undip.ac.id/index.php/izumi

\section{Conclusion}

The tea used in chanoyu is green powder tea called matcha, originally from the tea leaves without other ingredients. Meanwhile, in Yogyakarta Palace 2 Tang powdered tea is used. The ingredient of 2 Tang Tea comes from tea leaves that are mixed with jasmine. The utensils used in chanoyu are freely chosen by the host depending on the season and guests who attend. The utensil used in Yogyakarta Palace is Rampadan (tea utensil) that has been passed down from generation to generation.

The philosophy contained in chanoyu in the four principles is wa (harmony), kei (respect), sei (purity), and jaku (harmony). Harmony is seen in the interactions between participants, as well as between equipment and seasons. Within the Yogyakarta Palace, the presentation of tea is merely a form of Abdi Dalem's dedication to the king. Abdi Dalem Reso is assigned to prepare drinks which are routinely done at $6 \mathrm{am}$ and $11 \mathrm{pm}$. The nature of his total devotion, meaning that he never counted how long he was devoted to the king and what was asked for him.

The presentation procedure has similarities both in Chanoyu and Yogyakarta Palace. In the presentation procedure, each has regular movements, sequences, and a culture of giving honour.

\section{References}

Bengtsson, M. (2016). How to plan and perform a qualitative study using content analysis. Nursing Plus Open, 2, 8-14. https://doi.org/10.1016/j.npls.2016.01. 001

Britain, G. (2010). Japanese Tea Ritual : Religion in Practice Author ( $s$ ): Jennifer L . Anderson Published by:
Royal Anthropological Institute of

Great Britain and Ireland Stable

$U R L$ :

http://www.jstor.org/stable/2802501

JAPANESE TEA RITUAL : 22(3),

475-498.

Fajria Noviana. (2015). Kesederhanaan

Wabicha Dalam Upacara Minum Teh

Jepang. Izumi, 5, 1-7.

Genshitsu Sen, S. Sen. (2004). Urasenke

Chado Textbook. Tankosha.

Halim, G. T., Wicandra, O. B., Studi, P., Komunikasi, D., Seni, F., Kristen, U., Surabaya, P., Siwalankerto, J., \& Timur, J. (n.d.). JOGJAKARTA. 1-11.

Kastuti, T. I. (2018). Nilai Filosofis dalam Chanoyu. Japanese Research on Linguistics, Literature, and Culture, 1(1), 79-91. https://doi.org/10.33633/jr.v1i1.2129

Kuncoro, Y. A. (2018). Komunikasi Ritual Garebeg Di Keraton Yogyakarta. Jurnal ASPIKOM, 3(4), 623. https://doi.org/10.24329/aspikom.v3i4 .189

Macfarlane, A. (2004). The Empire pf Tea. The Overlook Press.

Magdalena, W., \& Nuswantoro, U. D. (2019). Prinsip Buddha Zen dalam Upacara Chanoyu Aliran Urasenke. 2(1), 93-107. https://doi.org/10.33633/jr.vlil.3445

Plutschow, H. E. (1986). Historical chanoyu. Tankosha.

Prof. Lee Jolliffe. (2007). Tea and Tourism. Channel View Publications,.

Santhi, H. S. (2016). Leaf it to Tea. Lans Brahmantyo. 
Soei, R. C. (2016). The book of chanoyu. Tankosha.

Somantri Ratna. (2014). The Story in A cup of Tea. Transmedia.

Soshitsu Sen XVI. (2010). Introductory Level.

Sugiyono. (2014). Metode Penelitian Pendidikan (Pendekatan Kuantitatif, Kualitatif, dan $R \& D)$. Alfabeta.

Suryawati, C. T. (2018). Cerminan Jiwa Chanoyu Dalam Pepatah Zen Yang Terdapat Pada Kakejiku. Ayumi: Jurnal Budaya, Bahasa, Dan Sastra, 5(1), 52-67. https://doi.org/10.25139/ayumi.v5i1.8 26 